\title{
A Novel Approach to Professional Development in Middle School Science: Instructional Coaching by University Professors to Improve the Instructional Core
}

\author{
Nadine Mchenry ${ }^{1, *}$, Laurie Borger ${ }^{2} \&$ Louise Liable-Sands ${ }^{3}$ \\ ${ }^{1}$ Science Teaching Center, Widener University, 216 Hyatt Hall, USA \\ ${ }^{2}$ School District's Science and Math department, Palisades School District, USA \\ ${ }^{3}$ College of Arts and Sciences, USA \\ *Correspondence: Science Teaching Center, Widener University, 216 Hyatt Hall, USA. Tel: 610-499-4259. E-mail: \\ ncmchenry@widener.edu
}

Received: August 10, 2017

Accepted: August 23, 2017 Online Published: September 18, 2017

doi:10.5430/jct.v6n2p59

URL: https://doi.org/10.5430/jct.v6n2p59

\begin{abstract}
The current study was constructed based on the recommendations of a previous study (McHenry \& Borger, 2013). Though inquiry-based teaching has long been touted as an effective pedagogy, its application by middle school science teachers has been problematic. Using tools developed from the previous study in conjunction with professional development grounded in instructional coaching, the program attempted to support middle school teachers in making informed instructional decisions that enhance classroom practices to support students in reaching full science proficiency. Over the two and one-half year span of the program, researchers found that middle school teachers were able to embrace major facets of the $5 \mathrm{E}$ model of inquiry. While their view of the nature of science expanded slightly, they still struggle with ideas related to argumentation and theory building. The impediments that influenced the success and continuation of the program were three-fold. There was a lack of administrative partnership due to a change in upper-level district leadership. The decision to adopt new curricular materials was counter to the goals of the inquiry-based teaching model and was adopted without discussion with the university coaches. There was inadequate time allotted to the program in the last year. Though administrative difficulties led to the discontinuation of the program, the enthusiasm exhibited by the middle level teachers speaks to the need for an instructional coaching partnership that provides this type of sustained, reform-based, transformational professional development that enhances the instructional core.
\end{abstract}

Keywords: instructional coaching; middle school science; inquiry-based teaching; 5E model

\section{Introduction}

Richard Elmore (2009) introduced the term instructional core in response to improving student learning at scales that make a difference. Elmore's fundamental point:

There are only three ways to improve student learning at scale: You can raise the level of content that students are taught. You can increase the skill and knowledge that teachers bring to the teaching of that content. And you can increase the level of students' active learning of the content. (p. 24)

The goal of the study was to improve science practices through instructional coaching to impact the instructional core. The current study was undertaken using the recommendations made by previous case studies (Authors, 2013) in conjunction with transformative, reform-based professional development scenarios that support collaboration among partners in examining the strengths and needs of learners, in understanding the nature of science and aspects of quality science instruction, in implementing the $5 \mathrm{E}$ model with fidelity, and in continually refining instructional practices to support all students in reaching science proficiency.

Reform-based professional learning situations create an environment for learning that is supported by research (Bransford, Brown, \& Cocking, 1999) because they support the belief that by encountering understandings of other learners, we gain and deepen our own understanding. A professional learning environment has the capacity to 
improve the instructional core because teachers can make informed changes in practice based in theoretic constructs. Through this instructional coaching process, teachers deepen their expertise in learning science content, practice integrating curriculum and learning experiences associated with science proficiency, and understand the need to learn instructional strategies that support students in developing their own scientific understanding as opposed to designing activities to help students remember science concepts and skills. Hence, the focus of this current study is to examine the effectiveness of this 2.5 year professional development learning partnership between middle level science teachers and university coaches. Therefore, the question that guided this research is as follows: What are the necessary components in a professional development partnership between university coaches and middle school science teachers that impact the instructional core?

\section{Conceptual Framework}

The instructional core in science rests on the belief that inquiry represents best practices that are based in the traditions of constructivism (Lowery, 2000). Constructivism recognizes that students come to the classroom with existing ideas. Students may not simply change their ideas because they have been told something to the contrary; instead they need to be given opportunities to actively engage in a learning environment that enables them to construct meaning from different experiences (Boddy, Watson, Aubusson, 2003).

The seminal works of Dewey's "educative experience" (1938), Duckworth's "wonderful ideas" (1987), and Vygotsky's "social discourse" (1978) are consistent with constructivism and form the theoretical foundation for inquiry-based teaching. Within their interactionist views, the focal point is neither the learner nor the environment, but rather the point of interaction that occurs as the learner navigates through the experiences of inquiry. In this construct, Dewey's symbiotic relationship reflects the belief that "educative experiences" are evoked through the participation of students with the environment as they create and become involved in the learning. Similarly, Duckworth's "wonderful ideas" brings in focus the notion that learners continually make new connections among ideas already mastered, while Vygotsky supports learning as making meaning through social interactions with each other and with the environment. Therefore, these seminal works support the idea that students learn best when they are actively engaged in their learning through: direct experience, reflective thinking, and social interactions.

Bybee's 5E model (1997) represents an integrated instructional sequence grounded in constructivist theory and more specifically interactionist constructs that support the development and refinement of an inquiry based learning community reaching for science proficiency. The engage/elicit phase provides opportunities for the teacher to state the purpose of student learning and create interest in the concept while uncovering pre-existing ideas and beliefs related to that concept. The explore phase facilitates question development by students and provides common experiences for students to work together without direct instruction from teacher. The explain phase is the most teacher directed step in the 5E's series in that it allows the teacher to help students compare their ideas (hypotheses, data collection, analyses, and conclusions), construct explanations, and justify them in terms of observations and data. Once the teacher has facilitated the students' accurate interpretation of findings, the students are able to apply concepts and explanations and make generalizations in the elaborate/expand phase. Finally, in the evaluate phase, students provide evidence of changes in their ideas, beliefs, and skills and compare their new understanding of the concept to their prior conceptualization. This series of instructional steps as outlined in the 5E model and applied within the context of a partnership between university coaches and middle school classroom teachers may have the capacity to improve the instructional core and improve student learning at scale by raising the level of content that students are taught, increasing the teachers' skill \& knowledge that they bring to teaching of that content, and increasing the level of students' active engagement with the content (Elmore, 2009).

\section{Literature Review}

\subsection{Science Proficiency for Students}

In the National Research Council's most recent report, Taking Science to School: Learning and Teaching Science in Grades $K-8$, (2007) scientific proficiency is represented by four strands of an intertwined rope. This model represents science as an interconnected way of thinking that is not static and is linked to the ability to initiate investigations that develop explanations or evaluate other's claims. Each strand of the rope represents an area of proficiency necessary for building a way of understanding the scientific enterprise. Students who are proficient in science:

1. know, use, and interpret scientific explanations of the natural world; 
2. generate and evaluate scientific evidence and explanations;

3. understand the nature and development of scientific knowledge; and

4. participate productively in scientific practices and discourse. (NRC, 2007, p. 36)

These new indicators of science proficiency represent a shifting view away from instruction focused solely on exploration and experimentation to instruction focused on explanation and theory building. With this shift, classroom inquiry changes from a mostly individual activity to one that is immersed in the social processes of a collaborative community of learners. Finally, the teacher's role shifts from the knowledge source and manager of hands-on activities to a facilitator of student's ideas and scientific discourse practices. Therefore, science instruction must shift priorities to engage students in classroom practices that incorporate all four strands in an effort to reach the new indicators of scientific proficiency.

\subsection{E Model}

The Committee on Science Learning (NRC, 2007) wrote the four strands of science proficiency to reflect a greater emphasis on the application of ideas, rather than the previously held notion that science instruction can be decomposed into content and process skill development. Collectively the four strands represent both knowledge building and reasoning skills that students need to cultivate in order to reach proficiency. While these shifting indicators change the instructional goals, Bybee's 5E model (1997) continues to provide instructional interactions necessary for students to encounter so that they can fully experience the scientific enterprise. Through self-reflection and interaction with their peers and the environment, Bybee (2006) contends that students will redefine, reorganize, elaborate, and change their initial thoughts to include new conceptual understandings. Additionally, he believes the 5E model will enable students to take an active role in their learning. Although there have been some researchers that deny its effectiveness (Chen and Klahr, 1999; Klahr and Nigam, 2004; Kirschner, Sweller \& Clark, 2006), Authors' (2013) synthesis of current research findings on Bybee's 5E model includes improving understanding by removing concept errors existing in their pre-information, creating positive subject matter knowledge, increasing scientific reasoning, and developing the cultivation of interest and positive attitudes about science. This suggests using the 5E model enhances student understanding.

\subsection{Instructional Coaching Embedded in Professional Development}

If the $5 \mathrm{E}$ model is an effective approach in helping students reach science proficiency, then teachers need to be able to use this instructional sequence so that it mirrors the theoretical underpinnings that support its effectiveness while shifting the focus of the instructional core to the new priorities of science proficiency. Therefore, teachers need to transform their understandings about what constitutes quality science instruction. Research points to the following specific barriers impeding this transformation: 1) a teacher's beliefs about the goals of science, 2) a teacher's knowledge base which includes subject specific knowledge, knowledge of inquiry pedagogy, and pedagogical content knowledge, 3) lack of well-developed science curriculum, 4) a teacher's knowledge base of instructional strategies, and 5) a lack of ongoing professional learning opportunities for teachers. (Erduran, Simon, \& Osbourne, 2004; Gess-Newsome \& Lederman, 1999; Haefner \& Zembal-Saul, 2004; Hershberger, Zembal-Saul, \& Starr, 2006; Magnusson, Krajcik, \& Borko, 1999; Metz, 2004; NRC, 2007; Simon, Erduran, \& Osbourne, 2009; Tippett, 2009; Weiss \& Pasley, 2004; Weiss, Banilower, McMahon, \& Smith, 2001; Vasquez, 2008).

Breaking through these barriers will not require a "more of the same" approach to professional development. Sparks and Hirsh (2007) contend that the professional development that most teachers receive is not of high quality. Frequently staff development programs are planned to merely fill required staff development time and meet necessary state requirements. These programs are often one-shot workshops that lack supportive follow up programs and therefore fail to bring about the necessary changes that result in improved student learning. (Schmocker, 2006; Sparks \& Hirsh, 1996) Many of these traditional staff development programs focus on adding new skills and knowledge without helping teachers to rethink, discard, or transform their thinking (Thompson \& Zeuki, 1999). This additive approach can result in teachers feeling overcome by the sheer volume of new things to try. Trying to change too many things too quickly can result in overwhelming the teachers to the point that nothing within their practice changes (Sparks \& Hirsh, 2007). Teachers are not given the time or the professional support to incorporate the new ideas into their classroom.

A transformative learning approach to staff development supports raising the level of content that students are taught, increasing the skill and knowledge that teachers bring to teaching that content, and increasing the level of students' active learning of the content (Elmore, 2009). In order to reach these student outcomes, teachers must transform their thinking and beliefs about teaching and learning. According to Thompson and Zeuki, (1999) there are five 
requirements necessary to create transformative learning experiences for teachers. First, create a high level of cognitive dissonance between teacher's beliefs, practices, and new information. Second, provide teachers with an opportunity to reflect, discuss, and make sense of the cognitive dissonance. Third, embed resolving activities in the teacher's situation and practice through the use of student work, videos, or engaging teachers as learners in student investigations. Fourth, provide time for teachers to develop new practices that fit with the new understandings that were created through the resolving activities. Finally, continually engage teachers in the process of improvement by supporting the development of new beliefs through transformational learning. This is not accomplished through a traditional professional development model.

Reform-based professional development is more effective than traditional professional development (Loucks-Horsley, Stiles, Mundry, Love, \& Hewson, 2010; Putnam \& Borko, 2000). Reform-based professional development requires more in-depth involvement than traditional professional staff development and could include on-going participation in any number of learning activities such as, professional learning communities, lesson design study, study groups, action research, case studies, tuning protocols, peer coaching, and mentoring. (Easton, 2004) What researchers have deemed essential is that reform-based professional development be results driven, site based, job-embedded, standards-based, curriculum linked, and sustained over time with extensive teacher input and collaboration that is directly linked to classroom expectations for student achievement (Schmocker, 2006; Frank, K.A., Zhao, Y., \& Borman, K., 2004; Sparks \& Hirsh, 2007).

The Committee on Science Learning (NRC, 2007) supports this view with their recommendations, which includes planning professional development to reflect a clear focus on improving student learning by engaging teachers with the specific curriculum they teach. Cornett and Knight (2009) state that teachers successfully implement new teaching strategies learned during professional development only about $15 \%$ of the time. However, when instructional coaching in the newly acquired teaching strategy follows the professional development program, successful implementation reaches $85 \%$. This increase in implementation rates of new instructional strategies by teachers can reflect the strong collaborative partnership instructional coaches build with teachers working in four specific areas: classroom management, content, instruction, and assessment (Knight, J., 2007). While instructional coaches are fairly common in literacy and mathematics, instructional coaching in science is currently rare and therefore, research literature on science coaching is sparse and limited to just a few studies. (DeChenne, Nugent, Kunz, Luo, Berry, Craven, \& Riggs, 2012)

Two descriptive studies of K-8 school based science coaching, found that instructional coaching supports teachers with the implementation of inquiry instruction in their classrooms and may have an impact on student achievement in science (Bransfield, Holt, \& Nastasi, 2007; Dempsy, 2007). Kraus's (2008) dissertation exploring school based science instructional coaching with high school science teachers concludes:

Coaching does indeed seem to be an effective method for removing the traditional barriers to inquiry and encouraging teachers to adopt inquiry- based teaching methods...The [study] coaching staff has been very successful in overcoming the usual inquiry difficulties stemming from a lack of inquiry knowledge, a lack of content knowledge, or inability to access materials. (Kraus, 2008, p. 169)

One, more recent, descriptive case study of a summer professional development program utilizing instructional coaches was a collaboration between a civil engineering department and an educational research center at a Midwest university. The goal of the program was to train a group of science teachers to act as coaches in supporting a group of middle and high school teachers in developing and implementing a guided inquiry lesson that used an engineering context to teach a math or science concept. This case study employs science coaches almost entirely within a summer professional development experience, rather than within the school year. The results from this study suggest science coaches can help teachers successfully develop and implement a guided inquiry lesson (DeChenne, Nugent, Kunz, Luo, Berry, Craven, \& Riggs, 2012).

A thorough review of the literature demonstrates the absence of university professors directly coaching middle school science teachers. The previously mentioned studies lack the professional development structure in which university professors serve as instructional coaches and mentors as they collaborate over multiple years with middle school science teachers directly. Transformative professional development programs of this type include instructional coaching that is school-based and job-embedded supporting science teachers in developing units of study, participating in lesson design studies, revising classroom management strategies, and assessing student work. Ideally this type of collaborative coaching partnership focuses on examining the strengths and needs of the learners in each teacher's classroom with the evidence drawn from research and clinical practice to provide teachers with an opportunity to build a coherent understanding of the instructional system within which they operate. Consistently, 
professional development researchers (Loucks-Horsley, S., Stiles, K.E., Mundry, S., Love, N., Hewson, P.W., 2010) are suggesting providing teachers with reform based professional development that will transform their understanding of the instructional core over time with collaborative colleagues.

In order for this type of on-going transformational professional development to occur over several years, teachers and school district leaders will need to be committed to sustaining teacher learning opportunities. Boyd, Banilower, Pasley, \& Weiss (2009) suggest eighty hours of professional staff development to facilitate changes in science instruction. Banilower (2007) and Banilower, Fulp, and Warren (2008) found significant improvements in student assessment scores when teachers were engaged in quality professional development conducted over time. Research is indicating that a substantial time investment is necessary to support teachers in designing instruction that reflects the scientific enterprise.

Based upon this literature to date, if school districts are to make science proficiency a goal for all students, then supporting teachers with high quality, transformational, reform-based professional development that meets their specific needs is essential. This includes improving student learning by focusing on the instructional core. This form of PD will require shifting teachers' beliefs and practices in the instructional core to embrace the theoretical underpinnings of the 5E model and current expectations of science proficiency.

\section{Description of the Partnership Program}

Instructional coaching in science is a novel approach to transformational, reform-based professional development that is capable of impacting the instructional core in middle level science education. Teacher resistance to utilizing alternative pedagogies, specifically the use of inquiry-based teaching, in middle school and upper elementary science classrooms is well documented (Wilson, Schweingruber, \& Nielsen, 2013). According to this same source, there is also evidence that professional development focused on the use of new pedagogies without ongoing, long-term support results in little to no change in teacher implementation of these new strategies (2013). The purpose of this study is to evaluate the effectiveness of a two and one-half year program of ongoing professional development focused on inquiry-based planning and teaching in an urban fringe school district (any school district within the metropolitan area of a city with greater than or equal to a populations of 250,000 (National Center for Education Statistics, 2013). Two university professors (teacher education and chemistry) and an elementary classroom teacher who also serves as an adjunct professor and specializes in science teaching comprise the team of researchers who act as instructional coaches.

In 2013/14, eight middle school teachers participated in an instructional coaching program with university professors through a series of seven professional development (PD) sessions that introduced them to the $5 \mathrm{E}$ model of inquiry and its basis in the interactionist worldviews of Dewey, Duckworth, and Vygotsky. The teachers participated in 12 hours of PD embedded with instructional coaching including three hours of unit plan development and revisions and three hours of video-taping those lessons, resulting in 18 hours of instructional coaching including face-to-face as well as continuous electronic input in the first year. These seven sessions and ongoing coaching provided participating teachers with opportunities to "do" inquiry as well as to examine the instructional plans/units that yielded these experiences as exemplars of the $5 \mathrm{E}$ model. Teachers reflected on the strengths and limitations of using inquiry and, using these reflections, designed instructional units with the support of the university coaches as well as science content specialists from the university. Teachers wrote their units using the same unit outline that was shared through the exemplars provided by the university coaches (See Appendix A). Once completed, teachers submitted their outlines to the university coaches who reviewed their work and provided feedback for revision based on the fidelity of the instructional unit and the 5E inquiry model. Teachers made adjustments to their plans and final drafts were then shared with the university coaches. Three real-time observations were conducted per teacher (via Adobe Connect) using the Classroom Observation Inventory (COI, see Appendix B) that had been co-developed by two of the university coaches in a previous study (Authors, 2013). Individual coaching sessions were scheduled to discuss teacher progress and questions related to the use of the 5E model. The remaining PD sessions focused on examining the areas of strengths and difficulties that teachers experienced in the planning and implementation of the 5E model.

Based on a review of teachers' instructional plans as well as observations and discussions of their implementation of these plans, the university coaches developed a second year's PD series that focused on strengthening those areas that were problematic and extending their work in areas where teachers seemed confident and proficient. In 2014/15, nine teachers participated. One of the original teachers retired and two new teachers joined the professional learning community. There were six PD sessions embedded with instructional coaching over the course of year two. The teachers participated in 21.5 hours of PD with coaching that involved three hours revising unit plans and three hours 
videotaping selected lessons resulting in 27.5 hours of PD in the second year. Again, coaching included continuous feedback and revision opportunities electronically. The first PD session required differentiated instruction for the new teachers to learn about the $5 \mathrm{E}$ model while the returning teachers were asked to build on the research findings from year one. All teachers were provided with additional exemplars of inquiry unit plans along with a targeted focus on releasing control, integration of the Common Core State Standards for Literacy, and the use of formative and summative assessments - recommendations that were gleaned from data collected in year one. Again, teachers developed 5E unit plans which they submitted to the coaches for review followed by revision and observations using the same protocol as in year one (see Appendix A and B). The only difference in protocol for year two was that observations were recorded asynchronously via a Swifl and videos were then shared in Dropbox.

Using the Essential Features of Classroom Inquiry and their Variation (Lowery, 2000) unit plans were evaluated to illustrate the level of teacher directed strategies used in year two as illustrated in Appendix C and Table 1 (see p. 21). Based on these findings, the first PD session for the final year began with coaching the middle level (ML) teachers to improve the explain phase of the 5E model by including argumentation discourse so that students had the opportunity to communicate multiple perspectives and defend those perspectives in the context of the nature of science investigation. The teachers participated in 7.5 hours of instructional coaching that included unit plan revisions and electronic communication between the university coaches and teachers. This brought the total PD learning opportunities for the middle level teachers to 55 hours plus continuous electronic communication over the two and one-half year PD program.

Based on their perceptions of the work completed using the $5 \mathrm{E}$ model and feedback regarding their use of inquiry and its importance in middle school science classrooms, the ML teachers recommended that the 5E model be replicated with the fifth grade teachers in their individual buildings to support their own self-efficacy with inquiry and to improve their colleagues' understanding of the curricular scope and sequence that embeds the $5 \mathrm{E}$ model. The university coaches and participating teachers proposed a teacher trainer model for year three. There were five sessions with three of these sessions facilitated by the university coaches and two facilitated by the middle level teacher trainers. After session one of year three, ML teachers became trainers of their respective schools' fifth grade teachers so they could pass on their understanding of the $5 \mathrm{E}$ model. The teacher-trainer model between the middle level teachers and their fifth grade colleagues is not part of this study.

\section{Method: Case Study and Grounded Theory Rationale}

This evolving PD series was examined as a case study, a common method used for conducting empirical investigations into a series of events over time; a methodology that can test theoretical models by applying and observing them in authentic contexts. Since case study research relies on multiple sources of evidence and the inclusion of pre-conceived theoretical constructs, case study methodology is well suited for this investigation (Merriam, 1998; Corbin \& Strauss, 2008).

In this particular case, the investigation regards the close inspection of a PD program that rotated around the consistent and theoretically sound planning and implementation of inquiry based unit plans in middle and upper elementary science classrooms. The study specifically examines the PD opportunities provided to in-service teachers and the ultimate effects of these experiences on teachers' pedagogical approaches. The methodology of this study can best be described as a qualitative intrinsic case study because no specific hypotheses were initially formulated but emerged as the study progressed.

Grounded theory was the method by which researchers analyzed their data from which themes emerged. The data was collected from teacher-designed unit plans and both real-time and asynchronous observations of their teaching using the Classroom Observation Inventory. The COI was used to review the unit plans and provide recommendations for revisions to help teachers more closely align their pedagogy with the $5 \mathrm{E}$ model. This inventory was also used to document what was observed on the videotaped lessons. All data was shared with participants at subsequent PD sessions through focused discussions that were transcribed by the researchers.

According to grounded theory, data is systematically collected and organized resulting in the emergence of core theoretical concepts. Researchers code and analyze their extensive notes to develop major themes that provide a rich understanding of the phenomena under study. In this tradition, no specific hypotheses are initially formulated but instead well-considered explanations emerge through the continual process of constant comparison analysis (Merriam, 1998; Corbin \& Strauss, 2008). Through the continuous process of constant comparison analysis a grounded theory emerges that represents a well-considered explanation for the phenomenon of interest (Trochim \& Donnelly, 2008). 
Grounded theory provided the opportunity to deeply explore the evolution of a PD program where teachers gradually learn to release control and move from teacher-centered presentation to student-centered inquiry. Traditionally, teachers convey final forms of knowledge, reinforce ideas that students have already learned, and provide vocabulary/definitions before having students consider evidence for that idea (Wilson, Schweingruber, \& Nielsen, 2013). By examining the unit plan outlines and teacher revisions of these plans alongside observations of the implementation of these plans and focused, transcribed discussions, the researchers were able to identify, reflect on, and create themes that can help to describe the necessary conditions that lead to an accurate, adequate, and appropriate application of the theoretic construct inquiry in the form of the $5 \mathrm{E}$ model.

\section{Discussion of Results}

The research question is: What are the necessary components of a professional development partnership between university coaches and middle school science teachers that impact the instructional core? The data collected and analyzed over the two and one-half years included both review and revision of written unit plans (six in year 1 and five in year 2), video reviews using the COI, and group discussions regarding the use of the 5E model. Four themes emerged from these data sets as issues that must be considered in the development of a PD partnership: teachers' perceptions of the nature of science, use of the $5 \mathrm{E}$ model, implications of implementing a literacy-based middle school science textbook, and instructional constraints.

\subsection{Theme 1: Teachers' Perceptions of the Nature of Science}

In year one, instruction during the engage/elicit, explore and explain phases supported building understanding through class cooperation. Students were working to form a collaborative conclusion based upon the class's evidence collection. During the engage/elicit phase, five of the six unit plans applied the constructs of this phase with fidelity. Six units accurately applied the explore phase. However, in the explain phase, only two units raised questions to challenge another's thinking or justify positions. Teachers orchestrated the instruction to create a predetermined understanding which is typical of the engage and explore phases; however during the explain phase, students should start to wonder beyond the obvious so that in the expand/elaborate phase, students have their own questions to investigate along with real world situations. It is in the wonderings that students start to have different viewpoints. There was no position driven discussions or opportunities for students to critically examine multiple perspectives. Teachers did not include discrepant events or conceptual probes to encourage difference of viewpoints.

Based on these findings, in year two, instructional coaching focused on facilitating student questions and argumentation discourse. As a result, the teachers incorporated word walls, concept maps, and wondering boards to support students' conceptual understanding in the engage/elicit and explore phases. However, there were no examples of teachers using these data sets to build student-led investigations nor were students asked to compile their explanations and reasoning into a scientific argument to present publically to the class. Without such presentations in the explain phase or follow-up use of these ideas in the elaborate/expand phase, whether formal or informal, children still do not have the opportunity to defend, refine, and rethink their arguments to develop a richer understanding of the phenomenon under study.

In year three, all participating middle level teachers shared their inquiry based learning techniques with teachers in the upper elementary science classrooms in their district. They became trainers for their colleagues. Though no new units were developed, implemented or observed, reflections from coaching sessions demonstrated the teachers' goal to change their own approach to the nature of science in the context of the $5 \mathrm{E}$ model and in turn, change those perceptions of the upper elementary $\left(5^{\text {th }}\right.$ grade teachers) to accommodate more learner-focused instruction that accommodates the use of their own thinking for explanatory purposes. Middle level teachers spoke about alternative ways to have students practice their oral explanation through the use of the word walls, which they developed a comfort with in year two. The middle school teachers rehearsed classroom explanation writing using claims, evidence, and reasoning (CER). Modeling how to debate different viewpoints within their coaching sessions was necessary for implementation in the classroom.

It is the contention of the National Research Council (2007) that students need to experience classroom practices that science is knowledge in use, or a theory building practice. In all units, students collected observations or researched facts and teachers facilitated a discussion to pull all ideas together into a greater understanding of the scientific principle under study. These discussions were designed to match student findings to predetermined theories and state-required content standards. Students were not defending or refining their own ideas. In contrast, for the scientific community, the goals of argumentation are to promote understanding of a phenomenon under study and to persuade other scientists of the validity of that specific idea. When claims do not fit their position, they try to 
integrate it into their thinking or refine their positions. In order to mimic this sort of scientific discourse and improve students' argumentation abilities, further coaching is necessary to promote the refinement of this part of the instructional core in middle level teachers.

\subsection{Theme 2: Use of the 5E model}

Teachers' use of the 5E model was examined using 'The Five Essential Elements of Inquiry' developed by the National Research Council (Lowery, 2000) and a synthesis of this data can be found in Table 1. The five essential elements of inquiry reflect the teachers' ability to release control throughout the $5 \mathrm{E}$ model and encourage student driven inquiry. Data from year two's units was categorized according to this release of control and highlighted in Table 1.

The first feature requires the learner to engage in scientifically oriented questions. In all cases, the middle level teachers continued to provide the questions rather than let the students develop their own. This illuminated the teachers' use of inquiry as a verification process, which resulted in the middle level science teachers being constrained by their need to lead the students to what they viewed as 'correct answers'. A focus on standardized test scores, limited classroom instructional time, and district curriculum mandates prohibited the middle level teachers from allowing the students the time to explore their own questions, a topic dealt with more specifically under Theme 4.

The second feature requires the learner to give priority to evidence in question responses. The middle level teachers did demonstrate proficiency in terms of allowing the learners to give priority to evidence in question responses. Three of the unit plans directed the learner to collect certain data while two of the unit plans allowed the learner to determine what evidence to collect. This demonstrates that two of the middle level teachers released control of evidence collection surrounding a teacher-selected question.

The third feature requires the learner to formulate explanations from evidence. There was a wider range of variation from teacher-centered to learner-centered approaches in attempts to create and implement inquiry-based unit plans. Three units guided the learner in the process of formulating an explanation; one unit provided the learner with ways to use evidence to build an explanation; and one unit provided the learner with evidence statements. The middle level teachers were encouraged to embed language arts writing strategies into their science units through multiple PD sessions to improve learners' ability to write scientific explanations in their own words. Two of the three coaches are college professors and can attest to the fact that this is one of the most difficult things to do! College science students struggle with scientific explanation. Three of the five science units did employ word walls and verbal rehearsal strategies, to provide learners with supports in writing scientific explanations that include claims, evidence and reasoning (CER).

The fourth feature requires the learner to connect explanations to scientific knowledge. Four of the science units directed the learners to sources of knowledge while one unit allowed the learner to examine other resources and form their own links to explanations. The ML teachers allowed the learners the freedom to make their own connections between their explanations and scientific principles. This illustrated the growing faith they had in their students' ability to link their own thinking to that of scientists.

The last feature requires the learner to articulate and justify explanations using multiple perspectives. This requires the learner to synthesize and evaluate their evidence and use it to form a meaningful scientific explanation. The teacher needs skills to facilitate higher-level, student-to-student discussions that will encourage the learners to build evidence-based explanations and participate in argumentation discourse from multiple perspectives. Three of the units provided guidelines for the learners to use for communicating their explanations and in two of the units, learners were coached in ways to communicate their explanations. In all five of the units the learners were able to communicate an explanation; however, none of the units rose to the level of reasoned argumentation. Overall, the teachers gained proficiency in the engage and explore phases of the $5 \mathrm{E}$ model. Their ability to use student explanations as a basis for sharing alternative viewpoints and defense of their hypotheses (Explain and Elaborate/Expand) and student reflection on their own understanding (Evaluate) continues to be the issues that could not be fully addressed due to time constraints. If professional development had been continued in this district, these areas would have become the basis for instructional coaching. 
Table 1. Essential Features of Classroom Inquiry and Their Variations

\begin{tabular}{|c|c|c|c|c|}
\hline \multicolumn{3}{|c|}{ More learner centered mode } & \multicolumn{2}{|r|}{ More teacher centered mode } \\
\hline $\begin{array}{l}\text { Essential } \\
\text { Feature }\end{array}$ & Variation & & & \\
\hline $\begin{array}{ll}1 . & \text { Learner } \\
\text { engages in } \\
\text { scientifical } \\
\text { ly oriented } \\
\text { questions }\end{array}$ & $\begin{array}{l}\text { and justifies } \\
\quad \text { explanations } \\
\text { Learner poses a } \\
\text { question }\end{array}$ & $\begin{array}{l}\text { reasonable } \\
\text { argument and } \\
\text { explanation } \\
\text { Learner selects } \\
\text { among questions }\end{array}$ & $\begin{array}{l}\text { Learner sharpens } \\
\text { teacher question }\end{array}$ & $\begin{array}{l}\text { Learner engages in question provided } \\
\text { by teacher }\end{array}$ \\
\hline $\begin{array}{ll}\text { 2. } & \text { Learner } \\
\text { gives } \\
\text { priority to } \\
\text { evidence } \\
\text { in question } \\
\text { response }\end{array}$ & $\begin{array}{l}\text { Learner determines } \\
\text { what is evidence and } \\
\text { collects it }\end{array}$ & $\begin{array}{l}\text { Learner is } \\
\text { directed to collect } \\
\text { certain data }\end{array}$ & $\begin{array}{l}\text { Learner is given } \\
\text { data to analyze }\end{array}$ & $\begin{array}{l}\text { Learner given data and told how to } \\
\text { analyze }\end{array}$ \\
\hline $\begin{array}{l}\text { 3. Learner } \\
\text { formulates } \\
\text { explanatio } \\
\text { ns from } \\
\text { evidence }\end{array}$ & $\begin{array}{l}\text { Learner formulates } \\
\text { explanations from } \\
\text { evidence summary }\end{array}$ & $\begin{array}{l}\text { Learner is guided } \\
\text { in process of } \\
\text { formulating } \\
\text { explanation }\end{array}$ & $\begin{array}{l}\text { Learner is given } \\
\text { possible ways to } \\
\text { use evidence to } \\
\text { build an } \\
\text { explanation }\end{array}$ & Learner provided with evidence \\
\hline 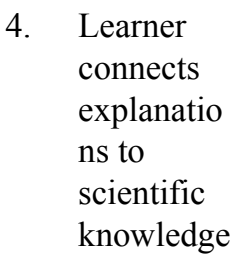 & $\begin{array}{l}\text { Learner examines } \\
\text { other resources and } \\
\text { forms links to } \\
\text { explanation }\end{array}$ & $\begin{array}{l}\text { Learner is } \\
\text { directed to } \\
\text { sources of } \\
\text { knowledge }\end{array}$ & $\begin{array}{l}\text { Learner is given } \\
\text { possible } \\
\text { connections }\end{array}$ & \\
\hline $\begin{array}{l}\text { 5. Learner } \\
\text { articulates }\end{array}$ & Learner forms & $\begin{array}{l}\text { Learner is } \\
\text { coached in } \\
\text { development of } \\
\text { communication }\end{array}$ & $\begin{array}{l}\text { Learner is given } \\
\text { guidelines for } \\
\text { communication }\end{array}$ & $\begin{array}{l}\text { Learner is given steps and procedures } \\
\text { for communication }\end{array}$ \\
\hline
\end{tabular}

Note. Adapted from Inquiry and the National Science Education Standards, 2000, National Academy Press.

\subsection{Theme 3: Implications of Implementing a Literacy-Based Middle School Science Textbook}

In year two, the school district selected a new science curriculum that supported the Common Core Literacy Standards. It was piloted and reviewed by selected middle school teachers without any input from university coaches with whom these teachers had worked. In the summer between year 2 and year 3, selected teachers wrote curriculum to match this new literacy-based textbook. When university coaches reviewed the new series with middle level teachers, it became very clear that though it did use the $5 \mathrm{E}$ model, the material was content rich and lacking in the processes of science. Each 5E sequence included content that went beyond state science standards, yielding an unmanageable amount of information even though teachers recommended that each grade level focus on depth rather than breadth. In addition, teachers need to look at their textbook as a resource, not a curriculum. This textbook series upon which the curriculum was based made implementation of authentic inquiry instruction impossible.

In year three, instructional coaches spent a considerable amount of time assisting middle level teachers in the prioritization of the most salient concepts in this overwhelming amount of content. According to teachers, the new curriculum is NOT useable as is. It does not allow for discernment of which textbook investigations are most important based upon PA core science standards for appropriate grade. The shift in focus from improving the instructional core to managing a content-rich textbook for the purposes of improving nonfiction reading resulted in diminishing the coaches' abilities to promote inquiry. Without coaching, teachers were left with questions regarding the use of the textbook rather than how to improve the instructional core. Implementation of this new textbook series and its inconsistency with authentic inquiry resulted in the demise of the coaching program, and ultimately the partnership. Even though the university coaches proposed a continuation of the program, the district administration proposed reverting to teacher-selected 'one-shot workshops' with no instructional coaching, collaboration, or 
continuity.

\subsection{Theme 4: Instructional Constraints}

There were several issues that came to the fore as a result of continuous discussions with and observations of participating middle school science teachers over the 2.5 year span of the partnership. In year one, observations of classroom practice yielded evidence to support the idea that teachers were trying out new ways of operating in their classrooms. All participating teachers seemed to run out of time in conducting their inquiry lessons, regardless of whether or not it was a 42 minute period or a block period. There was no time left for teachers to close the lessons and bring the children's thinking to a logical conclusion. Classroom procedures and instructions took 10-15 minutes to complete, further reducing the actual instructional time that teachers had available. Classroom management was problematic for many of the teachers as they attempted to improve their teaching and add new strategies to their instructional core.

In year two, the teachers use of time was much more focused but those who were limited to a 42-minute lesson continued to share their consternation regarding the seeming impossibility of doing what inquiry and the 5E model demands in such a short time period. In addition to time constraints, there were many additional interruptions that teachers identified as problematic. Intercom use and classroom telephone calls throughout lessons continually disturbed the instructional flow of teachers' lessons. In addition, children who have varying levels of learning difficulties were continually pulled from science class to attend additional classes in reading and math, therefore disrupting classroom work and also leaving huge holes in the science learning of those students.

Other obstacles and constraints that were identified and need to be addressed for a successful partnership to be effective in changing the instructional core include the following: Inquiry requires more teacher preparation and more time for students to complete activities in class. Inquiry teaching through big ideas and essential questions requires that teachers have the ability to understand the crosscutting concepts and big ideas in order to develop lessons that dig deep into understanding scientific phenomena rather than fall back on the superficial treatment of an overwhelming amount of science content. Teachers reported that they were not able to facilitate processing and/or questioning that connected hands-on science investigations to their textbook readings. Finally, teachers reported that the selection process for hiring teachers to write science curriculum MUST necessarily include teachers that are teaching science. Those $5^{\text {th }}$ grade teachers who teach all disciplines were not as receptive to the inquiry PD. They see it as more work.

\section{Conclusions}

The goal of the study was to improve science practices through instructional coaching to impact the instructional core. In order for this type of instructional coaching in science to occur over several years, teachers and school district leaders must be committed to sustaining teacher learning opportunities. Boyd, Banilower, Pasley, \& Weiss (2009) suggest eighty hours of professional staff development over several years to facilitate substantial changes in science instruction. Banilower (2007) and Banilower, Fulp, and Warren (2008) found significant improvements in student assessment scores when teachers were engaged in quality professional development conducted over time. Research is indicating that a substantial time investment is necessary to support teachers in designing instruction that reflects the scientific enterprise. The current study involved a total of 55 hours of transformational professional development in the form of instructional coaching over two and one-half years does not meet the standard set by Boyd et. al. (2009), Banilower (2007) and Banilower et. al. (2008).

Based upon this literature to date, if school districts are to make science proficiency a goal for all students then supporting teachers with high quality, transformational, reform-based, professional development in the form of instructional coaching is essential. Improving student learning by focusing on the instructional core will require shifting teachers' beliefs and practices to embrace the theoretical underpinnings of the 5E model and current expectations of science proficiency through transformational, reform-based professional development. The amount of time dedicated to this project over two and one/half years waned due to a change in administrative personnel as well as adoption of a literacy-based textbook. Therefore continual cultivation of teacher proficiency with inquiry through instructional coaching was limited over time.

Even though the teachers' time for PD was limited, the coaches were able to identify areas where teacher proficiency improved using the 5E model. The first area noted was the teachers' view of the nature of science. Through continuous instructional coaching, teachers demonstrated a gradual movement away from science as a set of discrete concepts to be learned and moved towards the belief that the scientific enterprise is dynamic. Their videotaped 
lessons demonstrated a gradual shift towards more rigorous outcomes and student-centered practices. It must be noted that the coaches had no evaluative role in the supervision of the teachers. In addition, teachers did not receive any university credits or remuneration in any form for their work as is the more traditional partnership model of professional development. Therefore, the teachers' desire to improve their practice was self-imposed and motivated by their own changing beliefs about the nature of science.

The second area identified was the teachers' support of the inquiry teaching practices of the 5E model. When areas of weakness were noted on the Classroom Observation Inventory, coaches offered teachers a variety of instructional strategies to improve their skill at increasing students' active learning. Through collaborative discussions teachers would willingly transform their unit plans to include these newly learned strategies. This continual refining of their unit plans increased the likelihood that the new instructional practices would be incorporated into their daily $5 \mathrm{E}$ lessons, further demonstrating their willingness to move towards a more inquiry based teaching pedagogy.

The one area of concern was the missing partnership between the district administration and the university coaches. Although coaches shared written reports at the conclusion of the first two years and goals and timelines were established at the start of the first two years, district administration did not actively engage with the university coaches. With this void, three areas of concern continued to plague the teachers: students continued to be pulled from science instruction for other curricular needs, inflexible building schedules locked most instruction into 42 minute periods, and the district selected new science curricular materials counterproductive to the goals of the two and one half-year professional development coaching program.

The teachers in this study truly wanted to change their view of the nature of science and embraced the $5 \mathrm{E}$ model as a valuable pedagogical approach. This is not normally the case when limited time is designated for science professional development as middle level teachers are continuing with their many everyday professional obligations. The enthusiasm exhibited by the middle level teachers speaks to the need for an instructional coaching partnership that provides this type of sustained, reform-based, transformational professional development that enhances the instructional core.

\section{References}

Banilower, E.R. (2007). Science: It's elementary; Year one evaluation report. Chapel Hill, NC: Horizon Research, Inc.

Banilower, E.R., Fulp, S.E., \& Warren, C.L. (2008). Science: It's elementary; Year two evaluation report. Chapel Hill, NC: Horizon Research, Inc.

Banilower, E.R., Boyd, S.E., Paisley, J.D., \& Weiss, I.R. (2006). Lessons from a decade of mathematics and science reform: A capstone report for the local systemic change through teacher enhancement initiative. Chapel Hill, NC: Horizon Research, Inc.

Boddy, N., Watson, K., \& Aubusson, P. (2003). A trial of the 5 E's: A referent model for constructivist teaching and learning. Research in Science Education, 33, 27-42. https://doi.org/10.1023/A:1023606425452

Boyd, S.E., Banilower, E.R., Pasley, J.D., \& Weiss, I.R. (2009). Progress and pitfalls: A cross-site look at local systemic change through teacher enhancement. Chapel Hill, NC: Horizon Research, Inc.

Bransford, J., Brown, A., \& Cocking, R. (1999). How people learn: Brain, mind, experience, and school. Washington DC: National Academy Press.

Bransfield, P., Holt, P., \& Nastasi, P. (2007). Coaching to build support for inquiry-based teaching. [News article]. Science Scope, 30(5), 49-51.

Bybee, R.W. (1997). Achieving scientific literacy, Portsmouth, NH: Heineman.

Bybee, R. W. (2006). Scientific inquiry and science teaching. In L.B. Flick \& N.G. Lederman (Ed.), Scientific inquiry and nature of science (pp. 1-14). Dordrecht, Netherlands: Springer.

Chen, Z., \& Klahr, D. (1999). All other things being equal: Children's acquisition of the control of variables strategy. Child Development, 70(5), 1098-1120. https://doi.org/10.1111/1467-8624.00081

Corbin, J., \& Strauss, A. (2008). Basics of qualitative research (3rd Ed.) Los Angeles, CA: Sage.

Cornett, J., \& Knight, J. (2009). Research on Coaching. In J. Knight (Ed.), Coaching: Approaches and perspectives (pp. 192-216). Thousand Oaks: Corwin Press. 
DeChenne, S., Nugent, G., Kunz, G., Luo, L., Berry, B., Craven, K., \& Riggs, A. (2012). A case study of coaching in science, technology, engineering, and math professional development. Lincoln, Nebraska: National Center for Research on Rural Education.

Dempsy, N. (2007). 5 elements combine in a formula for coaching. Journal of Staff Development, 28(2), 10-13.

Dewey, J. (1933). How we think. Lexington, MA: D.C. Heath.

Duckworth, E. R. (2010). The having of wonderful ideas and other essays on teaching and learning. New York, NY: Teachers College Press.

Easton, L.B. (2004). Powerful designs for professional learning. Oxford, OH: National Staff Development Council.

Elmore, R., (2009). Improving the instructional core. In R. Elmore, S. Fiarman, \& L. Teite (Ed.), Instructional rounds in education: A network approach in improving teaching and learning, (pp.249-238). Cambridge, MA: Harvard Education Press.

Erduran, S., Simon, S., \& Osbourne, J. (2004). TAPing into argumentation: Developments in the application of toulmin et al's argument pattern for studying science discourse. Science Education, 88, 915-933. https://doi.org/10.1002/sce.20012

Frank, K.A., Zhao, Y., \& Borman, K. (2004). Social capital and the diffusion of innovations within organizations: Application to implementation of computer technology in schools. Sociology of Education, 77(2), 148-171. https://doi.org/10.1177/003804070407700203

Gess-Newsome, J., \& Lederman, N.G. (1999). Examining pedagogical content knowledge. Dordrecht, The Netherlands: Kluwer Academic Publishers.

Haefner, L.A., \& Zimbal- Saul, C. (2004). Learning by doing? Prospective elementary teachers' developing understandings of scientific inquiry and science teaching and learning. International Journal of Science Education, 26(13), 1653-1674. https://doi.org/10.1080/0950069042000230709

Hershberger, K., Zembal-Saul, C., \& Starr, M. (2006). Evidence helps the KWL get a clue. Science and Children, 2, 50-53.

Kirschner, P.A., Sweller, J., \& Clark, R.E. (2006). Why minimal guidance during instruction does not work: An analysis of the failure of constructivist, discovery, problem based, experiential, and inquiry based teaching. Educational Psychologist, 41, 75-86. https://doi.org/10.1207/s15326985ep4102_1

Klahr, D., \& Nigam, M. (2004). The equivalence of learning paths in early science instruction: Effects of direct instruction and discovery learning. Psychological Science, 15, 661-667. https://doi.org/10.1111/j.0956-7976.2004.00737.x

Knight, J. (2007). Instructional coaching: A partnership approach to improving instruction. Thousand Oaks, CA: Corwin Press.

Kraus, R. (2008). Overcoming the difficulties of inquiry-based teaching through the use of coaching. Ph.D. Dissertation, Illinois Institute of Technology, Chicago, Illinois.

Loucks-Horsley, S., Stiles, K.E., Mundry, S., Love, N., \& Hewson, P.W. (2010). Designing professional development for teachers of science and mathematics. $\left(3^{\text {rd }}\right.$ Ed.) Thousand Oaks, CA: Corwin.

Lowery, L.F. (2000). Pathways to the science standards: Guidelines for moving the vision into practice-Elementary school edition. Arlington, Virginia: NSTA Press.

Magnusson, S.J., Krajcik, J., \& Borko, H. (1999). Nature, sources, and development of pedagogical content knowledge for science teaching. In J. Gess-Newsome, \& N.G. Lederman (Ed.), Examining Pedagogical content knowledge (pp. 95-132). Dordrecht, Netherlands: Kluwer Academic Publishers.

McHenry, N. \& Borger L. (2013). How can teacher-directed professional development lead to the identification, utilization, reflection on, and revision of $5 \mathrm{E}$ learning progressions? Electronic Journal of Science Education, $17(1), 1-24$.

Merriam S.B. (1998). Qualitative research and case study applications in education. San Francisco, CA: Jossey-Bass.

Metz, K. E. (2004). Children's understanding of scientific inquiry: Their conceptualization of uncertainty in investigations of their own design. Cognition and Instruction, 22(2), 219-290. 
https://doi.org/10.1207/s1532690xci2202_3

National Center for Education Statistics. (2013). Locale codes. Retrieved from https://nces.ed.gov/ccd/rural_locales.asp

National Research Council. (2007). Taking science to school: Learning and teaching science in grades K-8. Washington, DC: National Academy Press.

Putnam, R.T., \& Borko, H. (2000). What do new views of knowledge and thinking have to say about research on teachers learning? Educational Researcher, 29(1), 4-15. https://doi.org/10.3102/0013189X029001004

Schmocker, M. (2006). Results now: How we can achieve unprecedented improvements in teaching and learning. Alexander, VA: Association for Supervision and Curriculum Development.

Simon, S., Erduran, S., \& Osbourne, J. (2006). Learning to teach argumentation: Research and development in the science classroom. International Journal of Science Education, 28(2-3), 235-260. https://doi.org/10.1080/09500690500336957

Snowman, J., McCowen, R., \& Biehler, R. (2009). Psychology applied to teaching. Boston, MA: Houghton Mifflin Company.

Sparks, D., \& Hirsh, S. (2007). A national plan for improving professional development. Oxford, OH: National Staff Development Council.

Sparks, D., \& Hirsh, S. (1996). A new vision for staff development. Oxford, OH: National Staff Development Council.

Thompson, C.L., \& Zeuki, J.S. (1999). The frame and the tapestry: Standards- based reform and professional development. In L. Darling-Hammond \& G. Sykes (Eds.), Teaching as the learning profession: Handbook of policy and practice (pp. 341-375). San Francisco, CA: Jossey-Bass.

Tippett, C. (2009). Argumentation: The language of science. Journal of Elementary Science Education, 21(1), 17-25. https://doi.org/10.1007/BF03174713

Trochim, W. K., \& Donnelly, L. P. (2008). The research methods data base. Mason, OH: Cengage Learning

Vasquez, J. (2008). Tools \& traits for highly effective science teaching $K-8$. Portsmouth, NH: Heinemann.

Vygotsky, L. (1978). Mind in society: The development of higher psychological processes. Cambridge, MA: Harvard University.

Weiss, I.R., Banilower, E.R., McMahon, K.C., \& Smith, P.S. (2001). Report of the national survey of science and mathematics education. Chapel Hill, NC: Horizon Research, Inc.

Weiss, I.R., \& Pasley, S.D. (2004). What is high quality instruction? Educational Leadership, 61(5), 24-28.

Wilson, S., Schweingruber, H., \& Nielsen, N. (Eds.). (2013). Science teachers' learning: Enhancing opportunities, creating supportive contexts. Washington, DC: The National Academies Press. 


\section{Appendix A - 5E Unit Plan Outline}

\begin{tabular}{|c|c|c|c|c|}
\hline DATE: & GRADE LEVEL: & \multicolumn{2}{|l|}{ LENGTH: } & STANDARDS/THEMES: \\
\hline \multicolumn{5}{|l|}{ Unit Learning Objective: } \\
\hline 5E PHASES & EXAMPLES & LEARNING EXPERIENCES & MATERIALS & ASSESSMENT TASKS \\
\hline $\begin{array}{l}\text { ENGAGE/ELICIT } \\
* \quad \text { state purpose of the lesson } \\
* \quad \text { create interest } \\
* \quad \text { uncover pre-existing ideas and } \\
\text { beliefs } \\
\text { * create opportunities for students } \\
\text { to question/wonder }\end{array}$ & $\begin{array}{ll}* & \text { brainstorming } \\
* & \text { concept mapping/KWL } \\
* & \text { question production } \\
* & \text { discrepant event } \\
* & \text { demonstration } \\
* & \text { open-ended questions }\end{array}$ & $\begin{array}{l}\text { Learning Objective: } \\
\text { Activity: }\end{array}$ & & $\begin{array}{l}\text { Formative Assessment } \\
\text { Task: } \\
\text { Rating: }\end{array}$ \\
\hline $\begin{array}{l}\text { EXPLORE } \\
\text { * facilitate question development } \\
\text { by students } \\
\text { * provide common experiences for } \\
\text { students to work together } \\
\text { without direct instruction from } \\
\text { teacher }\end{array}$ & $\begin{array}{ll}* & \text { prioritize questions } \\
* & \text { group tasks } \\
* & \text { investigation } \\
* & \text { test ideas } \\
* & \text { research } \\
* & \text { learning centers }\end{array}$ & $\begin{array}{l}\text { Learning Objective: } \\
\text { Activity: }\end{array}$ & & $\begin{array}{l}\text { Formative Assessment } \\
\text { Task: } \\
\text { Rating: }\end{array}$ \\
\hline $\begin{array}{l}\text { EXPLAIN } \\
\text { * compare ideas (hypotheses, data } \\
\text { collection and analyses, } \\
\text { conclusions) } \\
\text { * construct explanations and } \\
\text { justify them in terms of } \\
\text { observations and data }\end{array}$ & $\begin{array}{ll}* & \text { reporting/presenting } \\
* & \text { group discussion } \\
* & \text { providing information } \\
& \text { for concept names and } \\
& \text { definitions }\end{array}$ & $\begin{array}{l}\text { Learning Objective: } \\
\text { Activity: }\end{array}$ & & $\begin{array}{l}\text { Formative Assessment } \\
\text { Task: } \\
\text { Rating: }\end{array}$ \\
\hline $\begin{array}{l}\text { ELABORATE/EXPAND } \\
\text { * apply concepts and explanations } \\
\text { in new contexts } \\
* \quad \text { make generalizations }\end{array}$ & $\begin{array}{ll}* & \text { further practical work } \\
* & \text { videos } \\
* & \text { debates } \\
* & \text { research } \\
* & \text { field trips }\end{array}$ & $\begin{array}{l}\text { Learning Objective: } \\
\text { Activity: }\end{array}$ & & $\begin{array}{l}\text { Formative Assessment } \\
\text { Task: } \\
\text { Rating: }\end{array}$ \\
\hline $\begin{array}{l}\text { EVALUATE } \\
\text { * provide evidence of changes in } \\
\text { student's ideas, beliefs and skills } \\
\text { * } \quad \text { compare prior knowledge to } \\
\text { newly formed ideas }\end{array}$ & $\begin{array}{ll}* & \text { refining materials } \\
& \text { developed in the engage } \\
& \text { phase } \\
* & \text { open ended questions } \\
* & \text { reflection prompts } \\
* & \text { summary of learning }\end{array}$ & $\begin{array}{l}\text { Learning Objective: } \\
\text { Activity: }\end{array}$ & & $\begin{array}{l}\text { Summative Assessment } \\
\text { Task: } \\
\text { Rating: }\end{array}$ \\
\hline
\end{tabular}




\section{Appendix B - Classroom Observation Inventory}

Teacher Name:

\begin{tabular}{|c|c|c|}
\hline $\begin{array}{l}\text { Stage - Circle } \\
\text { if observed }\end{array}$ & Teacher Behavior - check off those behaviors exhibited by the teacher & $\begin{array}{l}\text { Evidence - list examples } \\
\text { from lesson }\end{array}$ \\
\hline $\begin{array}{l}\text { Engage } \\
\text { Elicit }\end{array}$ & $\begin{array}{l}\text { 1.__ states the purpose of the lesson \& expectations for learning } \\
\text { 2.__ creates curiosity \& gets students' attention/focus } \\
\text { 3.__ raises appropriate questions } \\
\text { 4. elicits responses that uncover prior knowledge of the concept } \\
\text { 5. __ identifies \& records student thinking including any misconceptions } \\
\text { through formative probes, cartoons, discrepant events } \\
\text { 6. creates opportunities for students to question/wonder }\end{array}$ & \\
\hline Explore & 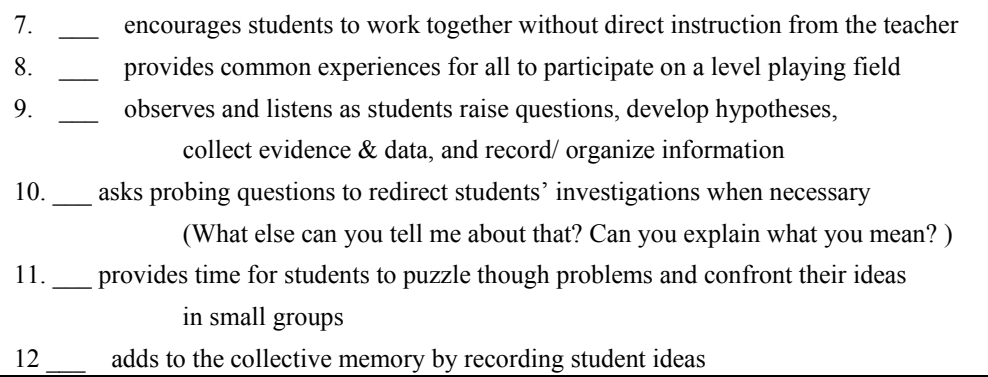 & \\
\hline Explain & 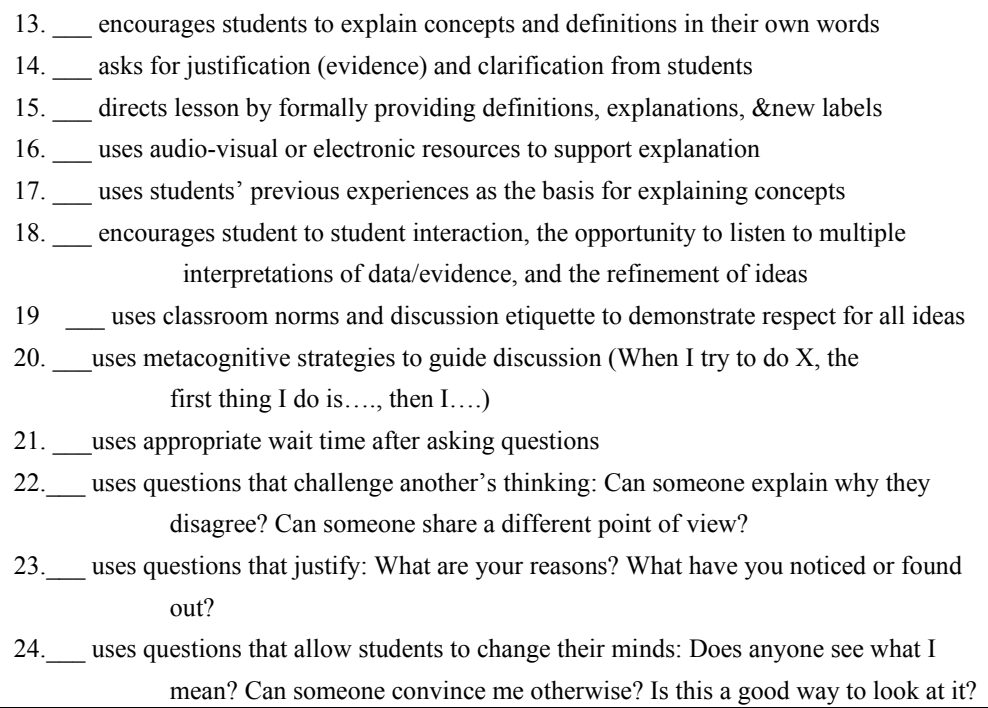 & \\
\hline $\begin{array}{l}\text { Elaborate } \\
\text { Expand }\end{array}$ & $\begin{array}{l}\text { 25.__ encourages students to use formal labels, definitions, and explanations provided } \\
\text { previously } \\
26 . \text { _ encourages students to apply or extend concepts and skills in new situations } \\
27 . \text { reminds students of alternative explanations } \\
28 . \text { refers students to existing data and evidence and asks "What do you already know?" } \\
\text { "Why do you think so?" }\end{array}$ & \\
\hline Evaluate & $\begin{array}{l}\text { 29.__ observes students as they apply new concepts or skills } \\
\text { 30._ looks for evidence that students have changed their thinking or behavior } \\
\text { (i.e., looks at prior knowledge of students at the engage phase) } \\
\text { 31.__ allows students to assess their own learning and group process skills } \\
\text { 32.__ asks open-ended questions, such as "Why do you think? What evidence do you } \\
\text { have? What do you know about x? How can you explain it?" } \\
\text { 33.__ brings closure to the lesson/unit } \\
\text { 34.__ evaluates collective memory of the class using the KWL or KWEL chart } \\
\text { 35._encourages students to self-assess their own conceptual understanding/reasoning }\end{array}$ & \\
\hline
\end{tabular}


Appendix C - Year 2 Unit Plans reviewed according to the Essential Features of Classroom Inquiry and Their Variations (Lowery, 2000)

Teacher directed inquiry: The National Research Council (2000) outlines the intellectual rigor of inquiry by synthesizing five essential elements of classroom inquiry. As shown in Table 1, the essential elements are positioned on the left to illustrate a more student-centered focus. The variations on the right represent a decreasing continuum of student initiated engagements.

\begin{tabular}{|c|c|c|c|c|c|}
\hline Essential Features & biomes & clouds & Fossil fuels & changes & weather \\
\hline $\begin{array}{l}\text { 1. Learner engages in } \\
\text { scientifically oriented } \\
\text { questions }\end{array}$ & $\begin{array}{l}\text { Learner engages in } \\
\text { question provided } \\
\text { by teacher }\end{array}$ & $\begin{array}{l}\text { Learner engages in } \\
\text { question provided } \\
\text { by teacher }\end{array}$ & $\begin{array}{l}\text { Learner engages in } \\
\text { question provided by } \\
\text { teacher }\end{array}$ & $\begin{array}{l}\text { Learner engages in } \\
\text { question provided by } \\
\text { teacher }\end{array}$ & $\begin{array}{l}\text { Learner engages in } \\
\text { question provided by } \\
\text { teacher }\end{array}$ \\
\hline $\begin{array}{l}\text { 2. Learner gives } \\
\text { priority to evidence } \\
\text { in question response }\end{array}$ & $\begin{array}{l}\text { Learner is directed } \\
\text { to collect certain } \\
\text { data }\end{array}$ & $\begin{array}{l}\text { Learner is directed } \\
\text { to collect certain } \\
\text { data }\end{array}$ & $\begin{array}{l}\text { Learner determines what } \\
\text { is evidence and collects } \\
\text { it }\end{array}$ & $\begin{array}{l}\text { Learner is directed to } \\
\text { collect certain data }\end{array}$ & $\begin{array}{l}\text { Learner determines what is } \\
\text { evidence and collects it }\end{array}$ \\
\hline $\begin{array}{l}\text { 3. Learner formulates } \\
\text { explanations from } \\
\text { evidence }\end{array}$ & $\begin{array}{l}\text { Learner is given } \\
\text { possible ways to } \\
\text { use evidence to } \\
\text { build an } \\
\text { explanation }\end{array}$ & $\begin{array}{l}\text { Learner is guided in } \\
\text { process of } \\
\text { formulating } \\
\text { explanation }\end{array}$ & $\begin{array}{l}\text { Learner is provided with } \\
\text { evidence }\end{array}$ & $\begin{array}{l}\text { Learner is guided in } \\
\text { process of formulating } \\
\text { explanation }\end{array}$ & $\begin{array}{l}\text { Learner is guided in } \\
\text { process of formulating } \\
\text { explanation }\end{array}$ \\
\hline $\begin{array}{l}\text { 4. Learner connects } \\
\text { explanations to } \\
\text { scientific knowledge }\end{array}$ & $\begin{array}{l}\text { Learner is directed } \\
\text { to sources of } \\
\text { knowledge }\end{array}$ & $\begin{array}{l}\text { Learner is directed } \\
\text { to sources of } \\
\text { knowledge }\end{array}$ & $\begin{array}{l}\text { Learner is directed to } \\
\text { sources of knowledge }\end{array}$ & $\begin{array}{l}\text { Learner is directed to } \\
\text { sources of knowledge }\end{array}$ & $\begin{array}{l}\text { Learner examines other } \\
\text { resources and forms links } \\
\text { to explanation }\end{array}$ \\
\hline $\begin{array}{l}\text { 5. Learner articulates } \\
\text { and justifies } \\
\text { explanations }\end{array}$ & $\begin{array}{l}\text { Learner given } \\
\text { guidelines for } \\
\text { communication }\end{array}$ & $\begin{array}{l}\text { Learner is coached } \\
\text { in development of } \\
\text { communication }\end{array}$ & $\begin{array}{l}\text { Learner given guidelines } \\
\text { for communication }\end{array}$ & $\begin{array}{l}\text { Learner is coached in } \\
\text { development of } \\
\text { communication }\end{array}$ & $\begin{array}{l}\text { Learner given guidelines } \\
\text { for communication }\end{array}$ \\
\hline
\end{tabular}

